\title{
Translation of Trendy Expressions as Extralinguistic Culture-bound References: the Case Study of If You Are The One
}

\author{
Ying Xie (Corresponding author) \\ Department of Media and Communication, Swinburne University of Technology, Australia \\ Email: yxie@swin.edu.au
}

Received: 08/07/2020

Accepted: 22/08/2020

Published: 01/09/2020

Volume: 1 Issue: 3

How to cite this paper: Xie, Y. (2020). Translation of Trendy Expressions as Extralinguistic Culture-bound References: the Case Study of If You Are The One. Journal of Critical Studies in Language and Literature, 1(3), 94-103

DOI: https://doi.org/10.46809/jcsll.v1i3.34

Copyright (C) 2020 by author(s) and Global Talent Academy Ltd. This work is licensed under the Creative Commons Attribution International License (CC BY 4.0).

http://creativecommons.org/licenses/by/4.0/

\section{(c) (i)}

\begin{abstract}
Since it was introduced into Australia from China in 2013, the Chinese-to-English subtitled dating game-show If You Are The One (Fei Cheng Wu Rao / 《非诚勿扰》) has been maintaining its super high ratings on the Australian national TV station SBS for all these years. The frequently appeared trendy expressions in IYATO, as the concentrated embodiment of Chinese popular culture, are the significant and inevitable difficulties to the interlingual subtitling of the show. On the premise that the trendy expressions in the text are regarded as Extralinguistic Culture-bound References (ECRs) (Pedersen, 2005, 2011), by employing the systematic translation strategy and influencing parameter proposed by Jan Pedersen (2005, 2011) for rendering and analyzing ECRs in audiovisual works, this paper aims to investigate the specific solution adopted by the subtitler in the translation of typical trendy expression cases in the latest season of the show, so as to bring inspiration and reference to the Chinese-to-English interlingual subtitling of the language-intensive shows in the future.
\end{abstract}

Keywords: Extralinguistic Culture-Bound References, Influencing Parameter, Translation Strategy, Trendy Expression

\section{Introduction}

\subsection{If You Are The One}

If You Are the One (Fei Cheng Wu Rao / 《非诚勿扰》) is the dating game show that enjoys particular popularity in China, which maintains its super high ratings among all the Chinese reality shows from 2010 to 2020 (TVTV. HK, 2020). Initially broadcast on Jiangsu Television Station on January 15, 2010, each episode of the speed-matching show lasts about 90 minutes, and it invites 24 female contestants as well as 3 male candidates for participation. Since its inception, Meng Fei has been the host of the show, and two psychologists are also invited to be his expert commentators. These two experts will comment on the three male candidates' speeches, interactions with the contestants, and their personalities throughout each episode. The show faithfully reflects the outlook on life, values, and views of marriage of ordinary single men and women in China, and shows the life of ordinary Chinese people.

In 2013, the Australian television station SBS (Special Broadcasting Services), the public channel founded in 1980 on the basis of the Australian government's policy on the "advocation of multilingualism and multiculturalism" (Dong \& Han, 2017, p. 57), introduced a total of 13 episodes of the first season of IYATO to Australia, and Prof. Jing Han, an expert of subtitle 
translation, undertook the leading role in the Chinese-to-English subtitling of the show. As soon as the show aired, it became very popular all over Australia. Being shown on SBS on a daily schedule with its current series Season 11 continuing into 2020 (Sun \& Han, 2020, p. 2), it has become Australia's longest-running non-English television program (Dong \& Han, 2017, p. 58), which positions IYATO as a successful case study for the export of Chinese audiovisual translation work.

1.2. Trendy Expressions as ECRs in IYATO

As a show based on the talk and interaction among female contestants and male candidates, there are two major challenges in the subtitle translation of IYATO, namely the translation of humor and trendy expressions (Dong \& Han, 2017, p. 58). Trend expressions intensively reflect China's current social and cultural spirit, which may not be familiar to a part of Chinese audience, let alone most target audiences in Australia. For example, in IYATO, the trendy expression “御姐” (Yujie) (Season 11 Episode 18. 27:28) is originated from the Japanese expression “御姉” (おねえ), which is often used to refer to mature and attractive women. The employment of this expression has been fully integrated into Chinese society. It is not only frequently utilized in people's daily communication, but it also involves the following kinds of text:

- Newspaper Title: Teacher of "Yu Jie" style encourages more than 200 students to start businesses online (Chutian Metropolis Daily, 2015)

- TV Drama Title: this expression is used in the title of the TV series Royal Sister Returns (Yujie Guilai/ 《御姐归 来》) broadcast on Chinese national television station CCTV in 2017.

- Online News: "Female stars of Yujie style become more and more popular now. They are women with different personalities from simple little girls." (Sohu.com, 2020)

In a word, bearing cultural characteristics of the society in a specific period, trendy expressions are widely used and have a profound influence in China. As an entertainment show that focuses on the public-concerned topic of blind dating, there are many trendy expressions in the dialogue between the host and guests. The high-quality subtitle translation of these expressions, which is the object of study in this paper, is also an essential reason for this show to obtain excellent feedback after its release in Australia.

Extralinguistic Culture-bound reference (ECR) refers to the "extralinguistic entity or process" that can only be interpreted by particular audience, even if she/he knows the language in question (Pedersen, 2005, p. 2). For instance, "Balenciaga" is an ECR that refers to the French luxury fashion house founded in 1917, and it can only be comprehended by people who are familiar with the global luxury market as well as this English expression. Trendy expressions also belong to ECRs proposed by Jan Pedersen $(2005,2011)$, which fall into the "encyclopedic knowledge" (ibid.) scope of the audience who know not only Chinese language, but also Chinese popular culture. To explain this further, the trendy expression “经济适用男” (Jingji Shiyongnan) (Season 11 Episode 20.37:20) in IYATO is often used to refer to men with "middle income and stable personality that is conducive to maintaining family harmony" (Xie, 2010, p. 2), which reveals Chinese women's new expectations of their spouses and their views on selection of future spouse. Undoubtedly, even if the audience know Chinese language, they may not able to fully interpret this referent with little knowledge regarding the social and cultural environment in which Chinese women live.

In the next section, I will elaborate on the theoretical framework mainly put forward by Jan Pedersen (2005, 2011) to analyze ECRs in the subtitle, and then apply it to the analysis of trendy expressions in IYATO.

\section{The Theoretical Underpinning}

\subsection{Translation Strategy}

The translation strategies for rendering ECRs brought up by Jan Pedersen $(2005,2011)$ can be summarized as follows:

\begin{tabular}{|c|c|c|c|}
\hline \multirow{2}{*}{$\begin{array}{l}\text { Translation } \\
\text { Strategy }\end{array}$} & \multirow[t]{2}{*}{ Introduction } & \multicolumn{2}{|c|}{ Example } \\
\hline & & ST & TT \\
\hline Retention & $\begin{array}{c}\text { The TT(Target Text) is exactly the } \\
\text { same as the ST(Source Text) }\end{array}$ & Dior & Dior \\
\hline \multirow[t]{2}{*}{ Specification } & $\begin{array}{l}\text { The TT contains more details to } \\
\text { specify the ST. }\end{array}$ & Bruce Lee & $\begin{array}{c}\text { 功夫大师李小龙 } \\
\text { (Back Translation: } \\
\text { Kung Fu Master Li } \\
\text { Xiaolong) }\end{array}$ \\
\hline & $\begin{array}{c}\text { The TT is the specified version of } \\
\text { the abbreviation of the ST. }\end{array}$ & $\mathrm{AI}$ & $\begin{array}{c}\text { 人工智能 } \\
\text { (Back Translation: } \\
\text { Artificial } \\
\text { Intelligence) }\end{array}$ \\
\hline
\end{tabular}




\begin{tabular}{|c|c|c|c|}
\hline Direct Translation & $\begin{array}{l}\text { The TT is the direct transfer from the } \\
\text { ST with no information added or } \\
\text { reduced. }\end{array}$ & Chocolate & 巧克力 \\
\hline Generalisation & The TT is a hypernym of the ST. & Jimmy Fallon & $\begin{array}{c}\text { 主持人 } \\
\text { (Back Translation: } \\
\text { The Host) }\end{array}$ \\
\hline \multirow[t]{2}{*}{ Substitution } & $\begin{array}{l}\text { The TT is a concept from the target } \\
\text { culture employed for the substitution } \\
\text { of that of the ST. }\end{array}$ & $\begin{array}{c}\text { 天子 } \\
\text { (Back } \\
\text { Translation: } \\
\text { Chinese } \\
\text { Emperor) }\end{array}$ & The King \\
\hline & $\begin{array}{l}\text { The TT is the paraphrased version of } \\
\text { the ST. }\end{array}$ & $\begin{array}{c}\text { 吃货 } \\
\text { (Back } \\
\text { Translation: } \\
\text { Foodie) }\end{array}$ & $\begin{array}{l}\text { People who like } \\
\text { various food }\end{array}$ \\
\hline
\end{tabular}

Based on Pedersen's categorization (Pedersen, 2005, p. 4), Source Language (SL) oriented strategies include Direct Translation, Specification, and Retention, whereas Target Language (TL) oriented strategies involve Substitution and Generalisation.

\subsection{Influencing Parameter}

In the process of subtitling audiovisual products, many influencing parameters may affect which translation strategy the subtitler ultimately chooses and his/her decision-making processes when facing the rendering of ECRs (Pedersen, 2011, p. 105). According to Pedersen's research methods, influencing parameters for the choice of ECR translation strategies can be divided into the internal influencing parameters and the external influencing parameters with the following respective subcategories.

\subsubsection{Internal Influencing Parameters}

1) Polysemiotics

According to Díaz Cintas (2004, p. 53), various music, images, etc. contained in audiovisual work will also be regarded as the "expletives" of subtitle, thus together making the audiovisual work become a polysemiotic text. Although the "expletives" (ibid.) require the subtitler to render comprehensively, the integrated effect, namely the "feedback effect" (Nedergaard-Larsen, 1993, p. 214), of these elements mainly works as an auxiliary for the audience's understanding. To a certain extent, the interplay of the subtitle and its "expletives" (ibid.) reduces the difficulty for the target audience in understanding information, as it serves to assist in elaborating the plot by integrating music, subtitles, pictures, etc., which all intend to reveal a certain content and create a particular atmosphere.

2) Centrality of reference

The subtitler must consider the significance of a particular ECR in the audiovisual work, so as to determine the final choice of subtitle translation strategies and processing method.

3) Transculturality

Based on the taxonomy of Pedersen (2005, p. 10), the degree of transculturality in ECRs can be classified into three levels, namely: (1) Microcultural ECR - this kind of ECR is rarely known, only a small group of ST audience or TT audience are familiar with it; (2) Monocultural ECR - only the ST audience are familiar with it; (3) Transcultural ECR - both the majority of ST audience and TT audience are familiar with it.

4) Extratextuality

Globalization has transformed the world into a closely linked integration. Some ECRs, as a concentrated expression of specific cultures, have also infiltrated into other cultures in the process of external communication, which realizes the "intertextuality" (Pedersen, 2005, p. 11) of ECRs considering that the Text Internal ECR has completed its transformation into the Text External ECRs. This kind of "intertextuality" (ibid.) of ECR presents the performing mechanism and positive results of ideal cultural communication. Again, such as Avatar (2009) directed by James Cameron, the role of Avatar in the film is very successful. The popularity of the film after its release in China is fully demonstrated by the fact that the protagonist in the Chinese film 《心花怒放》 (Breakup Buddies) (2004) not only dresses up as Avatar for her performance, but also appears as the image of Avatar on the official posters of this film. The transformation process shows the ECR of "Avatar" implementing its intertextuality from Text Internal to Text External, thus becoming a Transcultural ECR, which is a concrete representative of successful cultural dissemination case.

5) Media-specific Constraints

Different from the general translation in the text-to-text mode, interlingual subtitling of audiovisual works requires the mode transformation from spoken text to written text (Gottlieb, 1994), which may result in the "formalized in the transfer 
from Source Language to Target Language" (Pedersen, 2005, p. 14). Meanwhile, given the spatial limitation of screen, "the omission of lexical items from the original" is frequently employed with a subtitle limited to 32 to 41 characters per line in a maximum of two lines (Díaz-Cintas \& Remael, 2007, p. 9).

6) Co-text

Co-text refers specifically to the effect of the context of dialogue towards a comprehensive understanding of audiovisual works. The "co-textual redundancy" (Pedersen, 2011, p. 114) caused by dialogue context, namely the interplay of the ECR and its co-text, enables the subtitler to take the translation strategy of Omission when available since the content of ECR may have already been embedded within the co-text.

7) The Genre of Audiovisual Works

The subtitler chooses different translation strategies according to the different genres of audiovisual works (NedergaardLarsen, 1993, p. 221). Different genres of audiovisual works emphasize different information groups, and these specific information groups require the subtitler to perform specific detailed processing, which makes them accessible to the target audience.

Base on the summary of Nedergaard-Larsen (1993, p. 221), audiovisual works have three emphases: (1) "language is central" (2) "People are central" (3) "events are central". The subtitler divides the information emphasis of audiovisual works based on their genres, so as to pinpoint appropriate translation strategies for various genres.

2.2.2 External Influencing Parameter: Paratextual Considerations

Sometimes the subtitler is limited to specific considerations, such as the nature of the source text (Pedersen, 2011, p. 116), the characteristics of the target audience (Pedersen, 2011, p. 117), the particular broadcasting regulations (Pedersen, 2011, p. 118), and other pragmatic problems (ibid.). For example, these factors should also be considered: (1) The target audience's familiarity and love of source language culture.(2) When will the audiovisual work be shown etc. As this parameter focuses on the relationship between the text and the world instead of the text analysis itself, it is "not in the text, but rather about the text" (Pedersen, 2005, p. 14). Thus, it does not fall into the study scope of this paper.

Based on the above-mentioned theoretical underpinning for rendering ECRs, the paper seeks to progressively explore the following questions with the research corpus of IYATO (subtitled Australian version: Season 11 Episode 15- Episode 20):

(1) What solution does the subtitler use in translating trendy expression?

(2) What translation strategy does the subtitler employ in translating trendy expression?

(3) What internal influencing parameters may affect the subtitler's choice of translation strategy when rendering trendy expression?

Eventually, this paper attempts to answer the central question: what inspiration may get from the translation of trendy expression in IYATO for the future interlingual subtitling of ECRs in Chinese-to-English dating game shows?

\section{The Case Study}

\subsection{Features of Subtitle Translation on SBS Television Station}

Overseas programs broadcast by the SBS television station have always utilized English subtitles (Dong \& Han, 2017; Sun \& Han, 2020). It is expected that the original soundtrack will be retained to familiarize Australian audiences with different languages and present them with authentic pitch fluctuation of the audiovisual work. SBS has set up detailed regulations on the production of English subtitles. I consider the most important aspects are as follows, according to the subtitler Prof. Jing Han's interview (Dong \& Han, 2017): (1) No source language subtitles; only English subtitles will be shown at the bottom of the screen. (2) The English subtitles are in yellow font which boasts the strongest visibility on TV (Dong \& Han, 2017, p. 59) (3) The subtitle of each shot is set to stay on the screen for no more than two seconds with at most 26 letters (ibid.). 4) Up to two lines of subtitles can be presented for each shot (ibid.).

3.2 Translation Analysis of Trendy Expressions as ECRs in IYATO

In the subtitled Australian version of IYATO (Season 11), there are a large number of trendy expressions, such as “戏精” (someone be obsessed with role-playing) (Episode 20 13:29), “椬男” (bad guy) (Episode 20 13:59), “鸡汤” (chicken soup for the soul) (Episode 20 24:07), “女汉子” (tomboy) (Episode 20 32:38), and “吃货” (foodie) (Episode 18 47:50). These trendy expressions have reflected the current Chinese popular culture and social mainstream ideology, and are also the crux and difficulty of subtitle translation. In this section, I will analyze and discuss the typical translation cases of trendy expressions in IYATO (Season 11 Episode 15- Episode 20).

3.2.1 Trendy Expression as Noun

Example 1. Trendy Expression: 经济适用男 (financially efficient guy)

\begin{tabular}{|c|l|}
\hline \multicolumn{2}{|c|}{ Season 11 Episode 20.(37:20) } \\
\hline SL & TL \\
\hline 男嘉宾：现在我在杭州，有房有车有存款。 & $\begin{array}{l}\text { The Candidate: Now I live in Hangzhou } \\
\text { with a car, an apartment and savings. }\end{array}$ \\
\hline
\end{tabular}




\section{\begin{tabular}{|l|l|} 
男嘉宾：可以说是一个合格的经济适用男。 & The Candidate: I'm a financially efficient guy. \\
\hline
\end{tabular}}

Solution: the ST “经济适用男” is “a new concept of ideal male image proposed by modern women in China, which is a general term for a certain type of male" (Xie, 2010, pp. 1-2). In this scene, the candidate explained the meaning of this ECR by himself, and pointed out that the qualified “经济适用男” refers to the men who are with “a car, an apartment and savings". Therefore, the TT "financially efficient guy" not only reflects the meaning of the ST, but also causes no understanding problem to the target audience.

Translation strategy \& Internal influencing parameter: the subtitler uses the strategy of Direct Translation to render this ECR, and the target audience can understand the concept of ECR through the co-text.

Example 2. Trendy Expression: 送命题 (one that killed my chance)

\begin{tabular}{|l|l|}
\hline \multicolumn{1}{|c|}{ Season 11 Episode 20. (28:15) } \\
\hline \multicolumn{1}{|c|}{ SL } & \multicolumn{1}{|c|}{ TL } \\
\hline $\begin{array}{l}\text { 孟非: 有的女孩喜欢问自己的男朋友或老公 } \\
\text { 一些网络上很火的试探性问题。 }\end{array}$ & $\begin{array}{l}\text { The Host: Some girls likes to use questions that } \\
\text { are popular online to test their boyfriends or } \\
\text { husbands. }\end{array}$ \\
\hline 孟非: 你有遇到过让你受教的这类问题吗 ? & $\begin{array}{l}\text { The Host: Can you give us an example that } \\
\text { taught you a lesson? }\end{array}$ \\
\hline 男嘉宾 : 我以前遇到过一道送命题。 & $\begin{array}{l}\text { The Candidate: I had one that killed my } \\
\text { chance. }\end{array}$ \\
\hline
\end{tabular}

Solution: the literal meaning of the ST “送命题” is “a fatal question to answer". The candidate utilized this exaggerated ECR when talking with the host, which means that his ex-girlfriend had asked such a provocative question when they were in a romantic relationship, but he did not give the answer expected by her. The expression "kill my chance" in the TT can highlight the two key points that the ST intends to convey to the audience: "the ex-girlfriend's question is provocative", and "my answer does not meet her expectation."

Translation strategy \& Internal influencing parameter: the subtitler adopts the strategy of Substitution to render this ECR, which enables the target audience to comprehend the semantic essence of this ECR directly. Meanwhile, the target audience can interpret the referent of the "one" in the TT through co-text.

Example 3. Trendy Expression: 宝宝 (cute boy; boy)

\begin{tabular}{|c|c|}
\hline \multicolumn{2}{|l|}{ Scene 1: Season 11 Episode 18. (22:28) } \\
\hline SL & TL \\
\hline $\begin{array}{l}\text { 女嘉宾：我看你比我小啊，请问你会介意女 } \\
\text { 生比你年纪大吗? }\end{array}$ & $\begin{array}{l}\text { The Contestant: You are younger than me } \\
\text { Do you mind if your girlfriend is older than } \\
\text { you? }\end{array}$ \\
\hline $\begin{array}{l}\text { 孟非：这个宝宝看上去就不像谁家的男朋 } \\
\text { 友, 倒是像谁家的弟弟。 }\end{array}$ & $\begin{array}{l}\text { The Host: This cute boy doesn't look like } \\
\text { someone's boyfriend but younger brother. }\end{array}$ \\
\hline \multicolumn{2}{|l|}{ Scene 2: Season 11 Episode 16. (14:01) } \\
\hline SL & TL \\
\hline $\begin{array}{l}\text { 男嘉宾: 不要提前男友, 用行动和我一起改 } \\
\text { 正这个问题, 不是光说教, 她自己什么都不 } \\
\text { 干。 }\end{array}$ & $\begin{array}{l}\text { The Candidate: Don't mention her ex. } \\
\text { She should take action with me instead of just } \\
\text { preaching to me. }\end{array}$ \\
\hline 孟非：宝宝受了好多委屈。 & The Host: This boy has experienced a hard time. \\
\hline
\end{tabular}

Solution: the ST “宝宝” is mostly utilized to refer to an infant/a baby, or it is to be used as an affectionate nickname between lovers and couples. Nowadays, as a popular term widely employed by the public, this ECR is not limited to the above scope of application, it has been given various meanings. In the first scene, the female contestant asked the male candidate whether he cared about she was older than him or not. Then, the host commented about the male candidate's appearance and temperament, saying that the male candidate, namely the “宝宝”, looked like a younger brother to the female contestant. Thus, the ST “宝宝” is used to emphasize the childishness of the male candidate and the tenderness demonstrated 
by his appearance and behavior, which has been clearly revealed through the TT "cute boy". In the second scene, the male candidate was expressing his dissatisfaction to his ex-girlfriend. The host used the ST “宝宝” to refer to the candidate in order to portray him as a weak and bullied image in this romantic relationship. Therefore, the TT "boy" can not only appropriately highlight the characteristics emphasized within the ST, but also avoid the derogatory as well as offensive implication that may be suggested by using the straightforward expression of "baby" to describe the male candidate. Meanwhile, considering that the male candidate is high in stature, the TT "boy" employed by the host serves to portray his helplessness at that time even better.

Translation strategy \& Internal influencing parameter: according to different situations, the subtitler uses appropriate TT which can reflect the implied meaning in its ST through the strategy of Substitution. Especially in the second scene, the image of the polysemiotic text enables the target audience to interpret better the contrast effect between the tall male candidate and the TT "boy".

Example 4. ECR: 中央空调 (lady killer)

\begin{tabular}{|l|l|}
\hline \multicolumn{1}{|c|}{ Season 11 Episode 17. (46:47) } \\
\hline \multicolumn{1}{|c|}{ SL } & \multicolumn{1}{c|}{ TL } \\
\hline 女嘉宾 : 刚才您说您是一个暖男, & The Contestant: You said you're warm-heated. \\
\hline $\begin{array}{l}\text { 女嘉宾 : 我想问一下你是一个暖宝宝呢还是 } \\
\text { 一个中央空调? }\end{array}$ & $\begin{array}{l}\text { The Contestant: Are you a warm-heated baby or } \\
\text { a lady killer? }\end{array}$ \\
\hline
\end{tabular}

Solution: the literal meaning of the ST “中央空调” is “central air-conditioning”. It is often metaphorically used to refer to the attractive man who is gentle to all the women around him. Therefore, the TT "lady killer" directly reflects the referent of the ST, which enables the target audience's understanding of the contestant's question.

Translation strategy \& Internal influencing parameter: the subtitler employs the strategy of Substitution to render the ECR, which makes it familiar to the target audience.

3.2.2 Trendy Expression as Adjective

Example 1. Trendy Expression: 扎心 (sensitive)

\begin{tabular}{|l|l|}
\hline \multicolumn{1}{|c|}{ Season 11 Episode 15.(07:09) } \\
\hline \multicolumn{1}{|c|}{ SL } & \multicolumn{1}{|c|}{ TL } \\
\hline $\begin{array}{l}\text { 女嘉宾 : 我烦请你解释一下 } 80 \text { 后变成了中年 } \\
\text { 队伍是什么意思啊 ? }\end{array}$ & $\begin{array}{l}\text { The Contestant: Can you explain why you say } \\
\text { people born in 80s are now middle-aged? }\end{array}$ \\
\hline $\begin{array}{l}\text { 孟非: 我都过了扎心的年代了, 我已经无感 } \\
\text { 了。 }\end{array}$ & $\begin{array}{l}\text { The Host: I've passed my sensitive years. So I } \\
\text { have no feeling at all. }\end{array}$ \\
\hline
\end{tabular}

Solution: The ST “扎心” literally means “the sense of being stabbed into the heart”, which puts emphasis on something that is particularly touching and can cause intense ups and downs of emotion (Tao, 2017, p. 112). In this scene, the candidate addressed people born in the 1980s as "the middle aged" in his self-introduction video, which stirred controversy. The host quoted this ECR “扎心” in the dialogue to show that he no longer felt strongly uncomfortable or offended with such statements like before. Therefore, in the target language subtitle, the TT "sensitive" can express the host's emotional fluctuation in limited screen space.

Translation strategy \& Internal influencing parameter: the subtitler adopts the strategy of Substitution to render this ECR, which enables the target audience's comprehension of the ECR and keeps the length of the TT within the limited space of the screen.

Example 2. Trendy Expression: 中二 (silly)

\begin{tabular}{|l|l|}
\hline \multicolumn{2}{|c|}{ Season 11 Episode 20.(37:36) } \\
\hline \multicolumn{1}{|c|}{ SL } & \multicolumn{1}{|c|}{ TL } \\
\hline $\begin{array}{l}\text { 男嘉宾：可能我对于消费过于严苛，大家觉 } \\
\text { 得我是个死板的人。 }\end{array}$ & $\begin{array}{l}\text { The Candidate: I may be too strict with my } \\
\text { spending and people may think I'm rigid. }\end{array}$ \\
\hline 男嘉宾：但其实我也会中二，也会疯狂。 & The Candidate: But I can be silly and act crazy. \\
\hline
\end{tabular}


Solution: derived from the Japanese expression "chūnibyō", the trendy expression “中二” (silly) is a Text External ECR which refers to "psychological symptoms commonly suffered by children in junior high school who consider themselves as if to have a supernatural power" (Sari \& Anggraeny, 2017, p. 29). This expression is viral among young people in Asia, thus it can be categorized to Transcultural ECRs for them. However, the ECR is difficult for most Australian audiences to understand, making it a Monocultural ECR in the text of IYATO. In this scene, the male candidate used this ECR to describe himself, which was intended to express that he was not a particularly "rigid" person as people initially thought, and emphasized that he also enjoyed casual and childish moments in daily life. At the same time, considering the spatial limitation of subtitle translation, the subtitler renders this ECR as "silly" in the TT, which is enough to show the main point of the ST.

Translation strategy \& Internal influencing parameter: in consideration of the ECR's transculturality (Monocultural ECR), extratextuality (Text External ECR), and the media-specific constraint of subtitling, the subtitler uses the strategy of Substitution to render it.

Example 3. Trendy Expression: 宅 (like staying home)

\begin{tabular}{|l|l|}
\hline \multicolumn{1}{|c|}{ Season 11 Episode 17 (19:14) } \\
\hline \multicolumn{1}{|c|}{ SL } & \multicolumn{1}{|c|}{ TL } \\
\hline $\begin{array}{l}\text { 女嘉宾：虽然我平时都比较宅，但我还是很 } \\
\text { 喜欢冲浪这种运动。 }\end{array}$ & $\begin{array}{l}\text { The Contestant: Although I like staying home, } \\
\text { the sport I like is surfing. }\end{array}$ \\
\hline
\end{tabular}

Solution: the ST “宅” literally means "house” in Chinese. This expression is originated from the Japanese language "otaku", which is employed by the mainstream "as a stigmatizing label" for people who are obsessed with "anime, manga, and games and out of touch with everyday social reality" (Ito et al., 2012, p. xxi). Thus, it is a Monocultural ECR to Australia's target audience, and a Text External ECR originated from Japanese culture in IYATO. Nowadays, in China, with no negative connotation, the expression is mostly used to describe someone who prefers to simply stay at home rather than socialize with others, which is also the personal characteristics of the contestant in this scene. Therefore, the TT "like staying home" can demonstrate this point.

Translation strategy \& Internal influencing parameter: in consideration of the ECR's transculturality (Monocultural ECR) and extratextuality (Text External ECR), the subtitler uses the strategy of Substitution.

3.2.3 Trendy Expressions as Verb

Example 1. Trendy Expression: 打卡 (take a picture)

\begin{tabular}{|c|l|}
\hline \multicolumn{1}{|c|}{ Season 11 Episode 18. (32:32) } \\
\hline SL & \multicolumn{1}{|c|}{ TL } \\
\hline 孟非 : 每到一个城市都会想倒立打卡。 & $\begin{array}{l}\text { The Host: In each city, she takes a picture of } \\
\text { herself doing a headstand. }\end{array}$ \\
\hline
\end{tabular}

Solution: The ST “打卡” literally means “punch the clock”. Nowadays, more and more people like to take some exclusive photos in their travel destinations showing their various personalities, which is regarded as the complement of “打卡”. Therefore, the subtitler paraphrases what the ST intends to express, and the TT "take a picture" is enough to reveal the meaning of the ECR in this scene.

Translation strategy \& Internal influencing parameter: by using the strategy of Substitution, the subtitler renders the ECR into the expression familiar to the target audience.

Example 2: Trendy Expression: hold 不住 (can’t handle)

\begin{tabular}{|l|l|}
\hline \multicolumn{1}{|l|}{ Season 11 Episode 17.(22:16) } \\
\hline \multicolumn{1}{|c|}{ SL } & \multicolumn{1}{|c|}{ TL } \\
\hline 男嘉宾：你的打扮让我想起国外的范儿, & $\begin{array}{l}\text { The Candidate: Maybe your dress style is very } \\
\text { westernized. }\end{array}$ \\
\hline 男嘉宾：然后我觉得 hold 不住。 & The Candidate: So I feel I can’t handle you. \\
\hline
\end{tabular}

Solution: the ST "hold 不住” is originated from Taiwanese variety show College Talk (《大学生了没》), in which the comedian Xie Yilin mentioned this ECR several times in her performance, and then it began to be popular in the major Chinese media platforms (Jiang, 2012, p. 101). Literally translated as “can't hold”, the ST “hold 不住” actually means “being unable to handle appropriately or keep everything in control". In this scene, as the contestant's dress was too casual and very 
"westernized", the candidate then concluded that someone who fell in love with a girl of her style would not be able to play a leading role in the romantic relationship. Therefore, the TT "can't handle" shows the main idea of the ST in the limited space.

Translation strategy \& Internal influencing parameter: by using the strategy of Substitution, the subtitler renders the ECR into the expression familiar to the target audience.

Example 3: Trendy Expression: 䢃腿 (have an affair)

\begin{tabular}{|l|l|}
\hline \multicolumn{1}{|c|}{ Season 11 Episode 20. (47:28) } \\
\hline \multicolumn{1}{|c|}{ SL } \\
\hline $\begin{array}{l}\text { 男嘉宾：她那时候觉得我不能陪她去澳大利 } \\
\text { 亚, }\end{array}$ & $\begin{array}{l}\text { The Candidate: She felt that I couldn't go to } \\
\text { Australia with her. }\end{array}$ \\
\hline $\begin{array}{l}\text { 男嘉宾：然后就䢃腿了。这是我最不能接受 } \\
\text { 的。 }\end{array}$ & $\begin{array}{l}\text { The Candidate: She had an affair, which I } \\
\text { couldn't tolerate. }\end{array}$ \\
\hline
\end{tabular}

Solution: the ST “䢃腿” literally means “do the splits”, which is metaphorically used by the public as well as media to refer to the cause of the break-up of couples due to the appearance of a third party (Lin, 2012, p. 81). Therefore, the TT "have an affair" reveals the semantic essence of the ST.

Translation strategy \& Internal influencing parameter: by using the strategy of Substitution, the subtitler renders the ECR into the expression familiar to the target audience.

3.2.4 Trendy Expression as Phrase

Example 1. Trendy Expression: 点赞之交 (liking relationship)

\begin{tabular}{|l|l|}
\hline \multicolumn{1}{|c|}{ Season 11 Episode 18.(12:21) } \\
\hline \multicolumn{1}{|c|}{ SL } & \multicolumn{1}{|c|}{ TL } \\
\hline $\begin{array}{l}\text { 女嘉宾 : 我想告诉你有一种关系叫做点赞之 } \\
\text { 交。 }\end{array}$ & $\begin{array}{l}\text { The Contestant: There's a new relationship } \\
\text { called a “liking relationship". }\end{array}$ \\
\hline $\begin{array}{l}\text { 女嘉宾 : 不是所有的女生给你点赞就代表喜 } \\
\text { 欢你。 }\end{array}$ & $\begin{array}{l}\text { The Contestant: That a girl likes your posts } \\
\text { doesn't mean she likes you. }\end{array}$ \\
\hline
\end{tabular}

Solution: just as Facebook has its vast influence globally, WeChat is the social platform widely used by Chinese people. On WeChat, a particular interpersonal communication called “点赞之交” (liking relationship) has been formed among people through clicking the "like" icon on their friends' posts (Nie, 2015, p. 56). Since all major social platforms, including Facebook and Twitter, have this function, when the female contestant further explained "a girl likes your posts doesn't mean she likes you", the target audience are able to understand the TT "liking relationship" is intended to emphasize that the girl who clicked the "like" icon of the male candidate's post was only out of appreciation for the post content and politeness.

Translation strategy \& Internal influencing parameter: the subtitler uses the strategy of Direct Translation to render this $\mathrm{ECR}$, and the target audience can better interpret it through the co-text.

Example 2. Trendy Expression: 一眼见生死 (first impression)

\begin{tabular}{|l|l|}
\hline \multicolumn{1}{|c|}{ Season 11 Episode 19.(21:56) } \\
\hline \multicolumn{1}{|c|}{ SL } & \multicolumn{1}{c|}{ TL } \\
\hline $\begin{array}{l}\text { 女嘉宾: 刚才看你说到“一眼见生死”我还在 } \\
\text { 纠结这个问题。 }\end{array}$ & $\begin{array}{l}\text { The Contestant: I’m troubled by what you said } \\
\text { about first impression. }\end{array}$ \\
\hline
\end{tabular}

Solution: the ST “一眼见生死” literally means "being able to distinguish life and death at a glance”, which is used to describe someone's ability to make a quick judgment on something or a person based on the first impression. In this scene, the TT "first impression" is able to reveal the semantic essence of the ST within the limited space of the screen.

Translation strategy \& Internal influencing parameter: the subtitler successfully reveals the significance of the ECR within limited screen space by using the strategy of Substitution.

Example 3. Trendy Expression: 死亡三连问 (three questions)

Season 11 Episode 16. (29:43) 


\begin{tabular}{|l|l|}
\hline \multicolumn{1}{|c|}{ SL } & \multicolumn{1}{|c|}{ TL } \\
\hline $\begin{array}{l}\text { 男嘉宾 : 后来家里面安排过一些相亲我也去 } \\
\text { 了, }\end{array}$ & $\begin{array}{l}\text { The Candidate: My family then arranged blind } \\
\text { dates for me. }\end{array}$ \\
\hline $\begin{array}{l}\text { 男嘉宾 : 一坐下来就给我直接来了一个死亡 } \\
\text { 三连问。 }\end{array}$ & $\begin{array}{l}\text { The Candidate: Some girls asked me three } \\
\text { questions, }\end{array}$ \\
\hline 男嘉宾 : 房子在哪儿? & The Candidate: Where is your house? \\
\hline 男嘉宾 : 开什么车? & The Candidate: What car do you drive? \\
\hline 男嘉宾 : 收入多少? & The Candidate: How much do you earn? \\
\hline
\end{tabular}

Solution: the literal meaning of the ST “死亡三连问” is “three continuous fatal questions". Actually, it refers to the three offensive questions people encountered in a blind date, which have been shown in the candidate's following explanation. Thus, according to the context, the target audience can know what these three questions are and comprehend how obnoxious and flip these questions are, which is why they are metaphorically described as “死亡” (fatal) in the ST.

Translation strategy \& Internal influencing parameter: through the strategy of Generalization, the subtitler uses the hypernym to render this ECR, and the target audience can understand the content and emotion that the candidate intended to convey from the co-text - his subsequent explanation.

\section{Example 4. Trendy Expression: 山无陵天地合 (never)}

\begin{tabular}{|l|l|}
\hline \multicolumn{1}{|c|}{ Season 11 Episode 19. (27:16) } \\
\hline \multicolumn{1}{|c|}{ SL } & \multicolumn{1}{c|}{ TL } \\
\hline 女嘉宾：这件事对我打击特别大，在我心里 & The Contestant: This had a big impact on me as \\
本来是“山无陵天地合”他都不会离开我。 & I had thought he would never leave me \\
\hline
\end{tabular}

Solution: literally means "when mountains have no edges and corners, and when heaven and earth are integrated into one...", the ST “山无陵天地合” refers to something that is impossible to happen. This ECR is often used to describe the deep love and strong connection between lovers, as only in this particular situation can they be separated. In the famous Chinese TV drama My Fair Princess ( 《还珠格格》), the protagonist used this ECR to describe her loyalty to her lover, and then it started to frequently appear in the people's daily conversation and media platforms. Thus, this is a Monocultural ECR that is only familiar to the Chinese audience, and a Text External ECR that is originated from other audiovisual work. The subtitler renders it as the TT "never", which reveals the semantic essence of the ECR in the limited screen space.

Translation strategy \& Internal influencing parameter: through the strategy of Substitution, the subtitler successfully conveys the meaning of the ST under consideration of the media-specific constraint of subtitling, the ECR's transculturality (Monocultural ECR), and extratextuality (Text External ECR).

\section{Conclusion}

It can be seen from the translation analysis of trendy expressions in IYATO (Season 11 Episode 15-20) that the subtitler tends to employ the strategy of Substitution (TL oriented strategy), Generalization (TL oriented strategy), and Direct Translation (SL oriented strategy), from which the strategy of Substitution accounts for the most substantial proportion. Therefore, the translation strategies utilized by the subtitler for trendy expressions in IYATO are mostly TL oriented strategies, through which the subtitler can directly present the trendy expression in the familiar way of the target audience, so as to eliminate the obstacles of their understanding. When SL oriented strategies like Direct Translation are adopted, often, the co-text in IYATO has already served to explain the trendy expression, which enables the target audience to understand its meaning.

Based on the case study, the internal influencing parameters involved in the translation of trendy expressions in IYATO mainly include polysemiotic text, transculturality, extratextuality, media-specific constraint, and co-text. While co-text has the most considerable influence on the translation of trendy expressions, media-specific constraint, transculturality, and extratextuality also play significant roles. In terms of media-specific constraint, given that the genre of dating game show makes it fall into the category of language-intensive audiovisual work, the fast speaking speed and the large number of dialogues in the show also make it imperative to pay attention to this influencing parameter in interlingual subtitling. As discussed in detail in 3.1, the audience-oriented subtitle features of SBS have not only taken the audience's actual reading speed and the characteristics of foreign language programs into account, but also lay the foundation for IYATO's high audience acceptance. At the same time, there are many trendy expressions that originated from other cultures in the show, 
such as “御姐” (Yujie) (Season 11 Episode 18. 27:28) and “宅” (Zhai) (Season 11 Episode 17. 19:14) from Japanese culture. Therefore, it is also an essential step for the subtitler to cautiously judge on the transculturality and extratextuality of them.

To sum up, the subtitler of IYATO puts emphasis on the conciseness and fluency of its interlingual subtitling in order to make the language-intensive show easy to be accepted by the target audience. Thus, taking into account each internal influencing parameter with co-text as the primary one, the future subtitler can also consider using various translation strategies under the principle of the target audience's easy acceptance when rendering ECRs of Chinese-to-English languageintensive shows.

\section{References}

Díaz-Cintas, J., \& Remael, A. (2007). Audiovisual Translation, Subtitling. Manchester: St. Jerome.

Dong, H. Y., \& Han, J. (2017). Translation and dissemination of Chinese films and TV works in Australia-Interview with Dr. Han Jing, the chief subtitler of Australian national TV station SBS [中国影视作品在澳洲的翻译与传播一一澳 大利亚国家电视台 SBS 总字幕师韩静博士访谈]. Oriental Translation[东方翻译], 4, 56-61.

Chutian Metropolis Daily (2015, November 14, A12 Edition). Teacher of “Yu Jie” style encourages more than 200 students to start businesses online. [“御姐”老师带动 200 多名学生网上创业] [Newspaper] http://www.soundbarwilton.com/info/1015/2424.htm

Gottlieb, H. (1994). Subtitling: diagonal translation. Perspectives: studies in translatology, 2(1), 101-121. https://doi.org/10.1080/0907676X.1994.9961227

Ito, M., Okabe, D., \& Tsuji, I. (2012). Fandom unbound: Otaku culture in a connected world. New Haven and London: Yale University Press.

Jiang, C. Y. (2012). Courageous living needs to be under your control — On the Internet trendy expression “hold 住” [虎悍 的人生须“hold 住”一浅淡网络流行语“hold 住”]. Movie Review [电影评介], 5, 101-102.

Lin, L. L. (2012). “Duan Bei” and “Pi Tui” [“断背”与“䢃腿”]. Yuwen Yuekan [语文月刊, 4, 80-81.

Nedergaard-Larsen, B. (1993). Culture-bound problems in subtitling. Perspectives, 1(2), 207-240. https://doi.org/10.1080/0907676X.1993.9961214

Nie, X. Y. (2015). Liking relationship: The turn of interpersonal communication in the era of mobile Internet [点赞之交:移 动互联时代的人际交往转向]. Today's Massmedia [今传媒], 23(12), 56-57.

Pedersen, J. (2005). How is culture rendered in subtitles. Paper presented at the MuTra 2005: Challenges of Multidimensional Translation, Saarbrücken, May 2-6. http://www.euroconferences.info/proceedings/2005_Proceedings/2005_proceedings.html

Pedersen, J. (2011). Subtitling Norms for Television. Amsterdam: John Benjamins.

Sari, I. A. L., \& Anggraeny, R. (2017). CHŪNIBYŌ: psychological disorders in anime aura: MARYŪINKŌGA SAIGO NO TATAKAI. IRCS UNUD Journals, 1(1), 29-34

Sohu.com (2020, April 28). Who is your favorite “Yujie” style actress? [圈内御姐型女星, 你喜欢哪一个] [Netnews] https://www.sohu.com/a/391905193_234284

Sun, W., \& Han, J. (2020). If You Are the One and SBS: the cultural economy of difference. Media International Australia, 175(1), 1-14. http://dx.doi.org/10.1177/1329878X20906894

Tao, J. Y. (2017). Analysis of Internet buzzword “Zhaxinle, Laotie” [网络流行语“扎心了,老铁”探析]. Modern Chinese (Version of Linguistic Research)[现代语文(语言研究版)], 12, 111-112.

TVTV. HK (2020, August 10) Ratings of variety show as of August 8,2020 [2020 年8月 日综艺节目收视率排行榜] [TVTV.HK] http://www.tvtv.hk/archives/9201.html

Xie, Y. C. (2010). Linguistic interpretation of web word “economical and practical man” [网络词语“经济适用男”的语言学 阐释]. Journal of Ningbo Radio \& TV University [宁波广播电视大学学报], 8(4), 1-3+36 